BY VICTORIA J. FABRY, JAMES B. MCCLINTOCK, JEREMY T. MATHIS, AND JACQUELINE M. GREBMEIER

\title{
Ocean Acidification at High Latitudes: The Bellwether
}
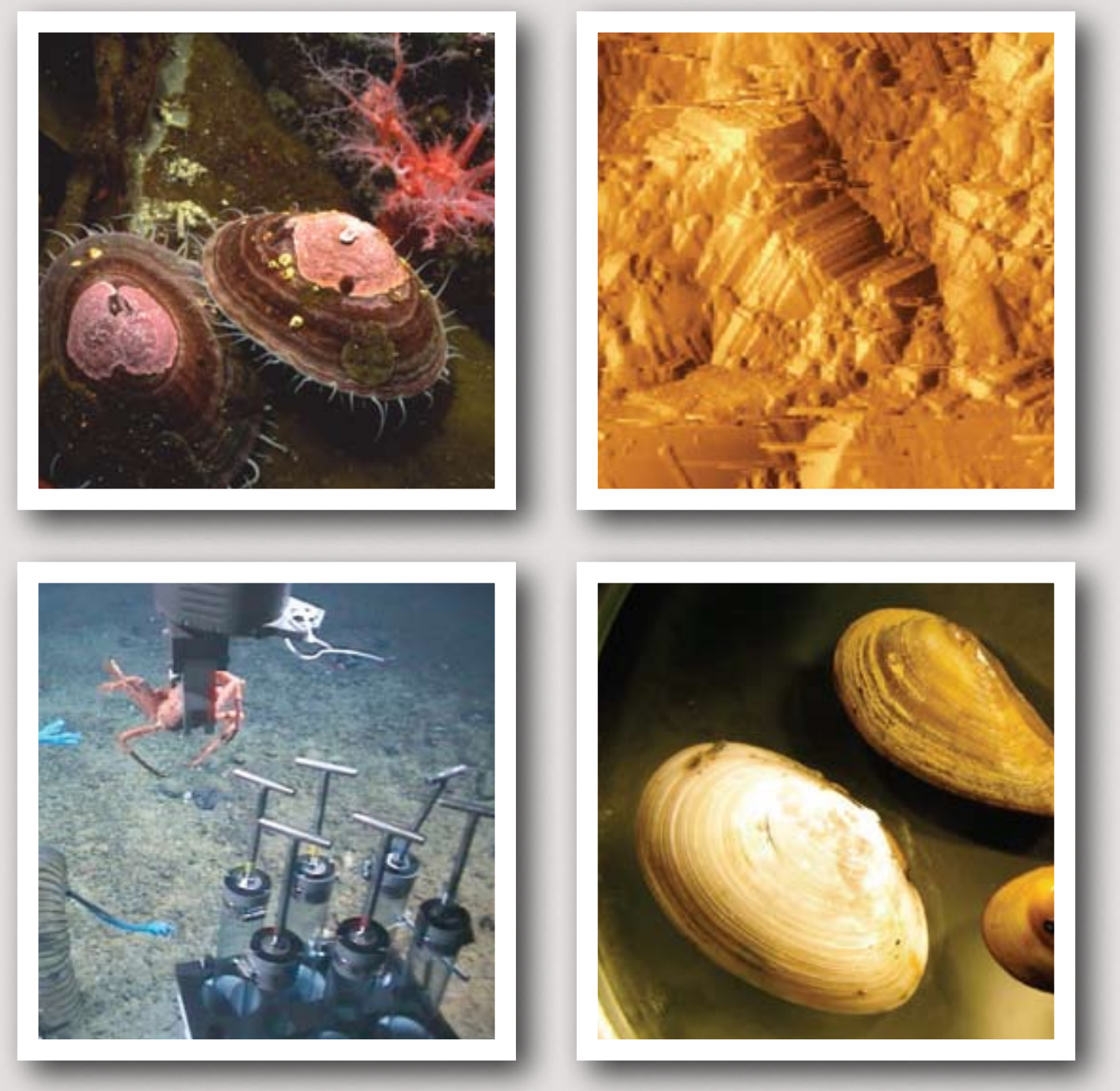
ABSTRACT. Owing to anthropogenic-induced acidification, surface waters of the high latitudes are projected to become persistently undersaturated with respect to aragonite as early as mid-century. Seasonal aragonite undersaturation in surface and shallow subsurface waters of some northern polar seas has already been observed. Calcified marine organisms, including thecosomatous pteropods, foraminifers, cold-water corals, sea urchins, molluscs, and coralline algae, make up significant components of the rich communities in high latitudes, and they are thought to be at risk with increasing ocean acidification. Over the next decades, trends of rising temperatures and species invasions coupled with progressive ocean acidification are expected to increasingly influence both planktonic and benthic marine communities of Antarctica and the Arctic. The rate and magnitude of these changes underscore the urgent need for increased efforts in ocean acidity research and monitoring in polar and subpolar seas.

\section{PRESENT AND PROJECTED CHANGES IN SEAWATER CARBONATE CHEMISTRY}

High-latitude regions have naturally low carbonate ion concentrations, owing to increased $\mathrm{CO}_{2}$ solubility, the sensitivity of acid-base dissociation coefficients at cold temperatures, and ocean mixing patterns. As a result, seawater saturation states with respect to calcium carbonate $\left(\mathrm{CaCO}_{3}\right)$ minerals are lower at high latitudes than in temperate and tropical regions. Although surface waters of high-latitude regions today generally are supersaturated with respect to aragonite, new results show areas of aragonite undersaturation in some northern polar seas (Yamamoto-Kawai et al., 2009; Bates et al., 2009; recent work of author Mathis and colleagues). With current $\mathrm{CO}_{2}$ emission rates, models project that surface waters of the Southern Ocean, Arctic Ocean, and parts of the subarctic Pacific will become undersaturated with respect to aragonite by the end of this century
(Orr et al., 2005; Steinacher et al., 2009; Feely et al., 2009). Thus, high-latitude seas are a bellwether for prospective impacts of ocean acidification on marine organisms at mid and low latitudes. Because of the large and rapid rates of change now underway in polar seas, these regions constitute ecosystem laboratories for diverse studies in ocean acidification aimed at investigating its effects on physiological processes and action mechanisms, assessing potential acclimation and adaptation, and modeling future impacts at population, community, and regional scales.

\section{The Southern Ocean}

The Southern Ocean is a major region of oceanic uptake of anthropogenic $\mathrm{CO}_{2}$, with about $40 \%$ of the total ocean inventory of anthropogenic $\mathrm{CO}_{2}$ entering south of $40^{\circ} \mathrm{S}$ (Sabine et al., 2004; Khatiwala et al., 2009). In the Southern Ocean south of $60^{\circ} \mathrm{S}$, the average depth of the aragonite saturation horizon currently is about $730 \mathrm{~m}$ (Feely et al., 2004; Orr et al., 2005). Based on model outputs from 13 ocean models and global gridded data (Key et al., 2004), Orr et al. (2005) developed scenarios for future changes in surface ocean carbonate chemistry as a function of changes in atmospheric $\mathrm{CO}_{2}$. Under the Intergovernmental Panel on Climate Change's (IPCC's) IS92a business-as-usual emissions scenario through the year 2100, the aragonite saturation horizon in the Southern Ocean is expected to progressively shoal to the surface ocean when seawater $p \mathrm{CO}_{2}$ values approach 560 ppmv, which could occur by mid century (Orr et al., 2005; Steinacher et al., 2009; Feely et al., 2009). When seasonal variability of the carbonate chemistry is considered, however, aragonite undersaturation is projected to occur during wintertime as early as 2030 (McNeil and Matear, 2008). Because calcite is less soluble in seawater than aragonite, calcite undersaturation in surface waters is predicted to occur later as seawater $p \mathrm{CO}_{2}$ reaches 900 ppmv (Orr et al., 2005; Fabry et al., 2008).

\section{The Arctic Ocean}

Two types of forcing are driving increased ocean acidification in the Arctic Ocean and its marginal seas: loss of sea ice and high rates of primary productivity over the continental shelves coupled with increased ocean uptake of anthropogenic $\mathrm{CO}_{2}$. In the central basin of the Arctic Ocean, particularly on the western side (Canada and 
Makarov basins), high rates of seasonal productivity over the shelves draw down $p \mathrm{CO}_{2}$ in surface waters. As these shelfmodified waters are exported offshore, the perennial ice cover has, until recently, prohibited significant equilibration with the atmosphere, creating a polar mixed layer that is undersaturated with respect may enhance the air-to-sea $\mathrm{CO}_{2}$ flux by 28\% per decade (Bates et al., 2006).

Rising atmospheric $\mathrm{CO}_{2}$ levels combined with the opening of the central Arctic Ocean due to warming and sea ice retreat will lead to higher $p \mathrm{CO}_{2}$ values in the surface waters of the basin and reduced $\mathrm{CaCO}_{3}$ saturation states $(\Omega)$.

BECAUSE SURFACE WATERS IN HIGH LATITUDES WILL BE THE FIRST OCEAN REGIONS TO BECOME PERSISTENTLY UNDERSATURATED WITH RESPECT TO ARAGONITE AS A RESULT OF HUMAN ACTIVITIES, POLAR AND SUBPOLAR SEAS ARE A BELLWETHER FOR GLOBAL OCEAN ACIDIFICATION.

to atmospheric $\mathrm{CO}_{2}$. However, the rapid retreat of summertime sea ice cover has exposed these waters to the atmosphere, allowing for enhanced air-sea exchange, and increased the sink for atmospheric

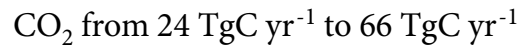
over the past three decades (Bates et al., 2006). Furthermore, melting of sea ice reduces the $\mathrm{CaCO}_{3}$ saturation state of seawater, primarily by reducing alkalinity (Steinacher et al., 2009). Seasonal aragonite undersaturation of surface waters in the Canada Basin has already been observed (Yamamoto-Kawai et al., 2009; Bates et al., 2009). Future sea ice melting
Along with decreasing $\mathrm{CaCO}_{3}$ saturation states at the ocean's surface, the bottom waters over the continental shelves are also at risk from ocean acidification. Seasonally intense primary productivity is decoupled from grazing on the Chukchi Sea shelf, leading to high rates of export production with particulate carbon being remineralized in the bottom water and sediments. During the summertime sea ice retreat period, high rates of phytoplankton primary productivity decrease the $p \mathrm{CO}_{2}$ of the surface waters over the shelf, causing the seawater $\mathrm{CaCO}_{3}$ saturation states to

Victoria J. Fabry (fabry@csusm.edu) is Professor, Department of Biological Sciences, California State University, San Marcos, CA, USA. James B. McClintock is Endowed University Professor of Polar and Marine Biology, Department of Biology, University of Alabama at Birmingham, Birmingham, AL, USA. Jeremy T. Mathis is Assistant Professor, Institute of Marine Science, University of Alaska Fairbanks, Fairbanks, AK, USA. Jacqueline M. Grebmeier is Research Professor, Chesapeake Biological Laboratory, University of Maryland Center for Environmental Science, Solomons, MD, USA.

increase, while subsurface waters become undersaturated with respect to aragonite, due primarily to $p \mathrm{CO}_{2}$ increases from the remineralization of particulate organic carbon (Figure 1; Bates et al., 2009). This seasonal response involving phytoplankton productivity and seawater $\mathrm{CaCO}_{3}$ saturation state causes the aragonite saturation state to drop below the saturation horizon $\left(\Omega_{\mathrm{ar}}=1\right)$ at a depth of 40-150 m over the northern Chukchi Sea shelf and in the Canada Basin within upper halocline waters located between 100- and 200-m depth (Bates et al., 2009). The seasonal aragonite undersaturation in subsurface waters over the Chukchi Sea shelf is hypothesized to be a recent phenomenon driven by the uptake of anthropogenic $\mathrm{CO}_{2}$ and subsurface remineralization of organic matter. Such aragonite undersaturation will likely be exacerbated and persist longer over the shelf in the future because of increases in anthropogenic $\mathrm{CO}_{2}$ loading in the atmosphere and possible increases in productivity over the shelf resulting from warming and longer ice-free periods (Bates and Mathis, 2009).

Model studies suggest that the effects of future increases in atmospheric $\mathrm{CO}_{2}$ and climate change on the carbonate chemistry of the Arctic Ocean will lead to aragonite undersaturation in the near term (Orr et al., 2006; Steinacher et al., 2009). The Steinacher et al. (2009) model simulation predicted the beginning of aragonite undersaturation in some Arctic surface waters would occur within a decade, when atmospheric $\mathrm{CO}_{2}$ reaches 409 ppm. When atmospheric $\mathrm{CO}_{2}$ increases to $552 \mathrm{ppm}$, which occurs in the year 2054 under the A2 businessas-usual emissions scenario, $50 \%$ of the Arctic Ocean's surface area is projected 


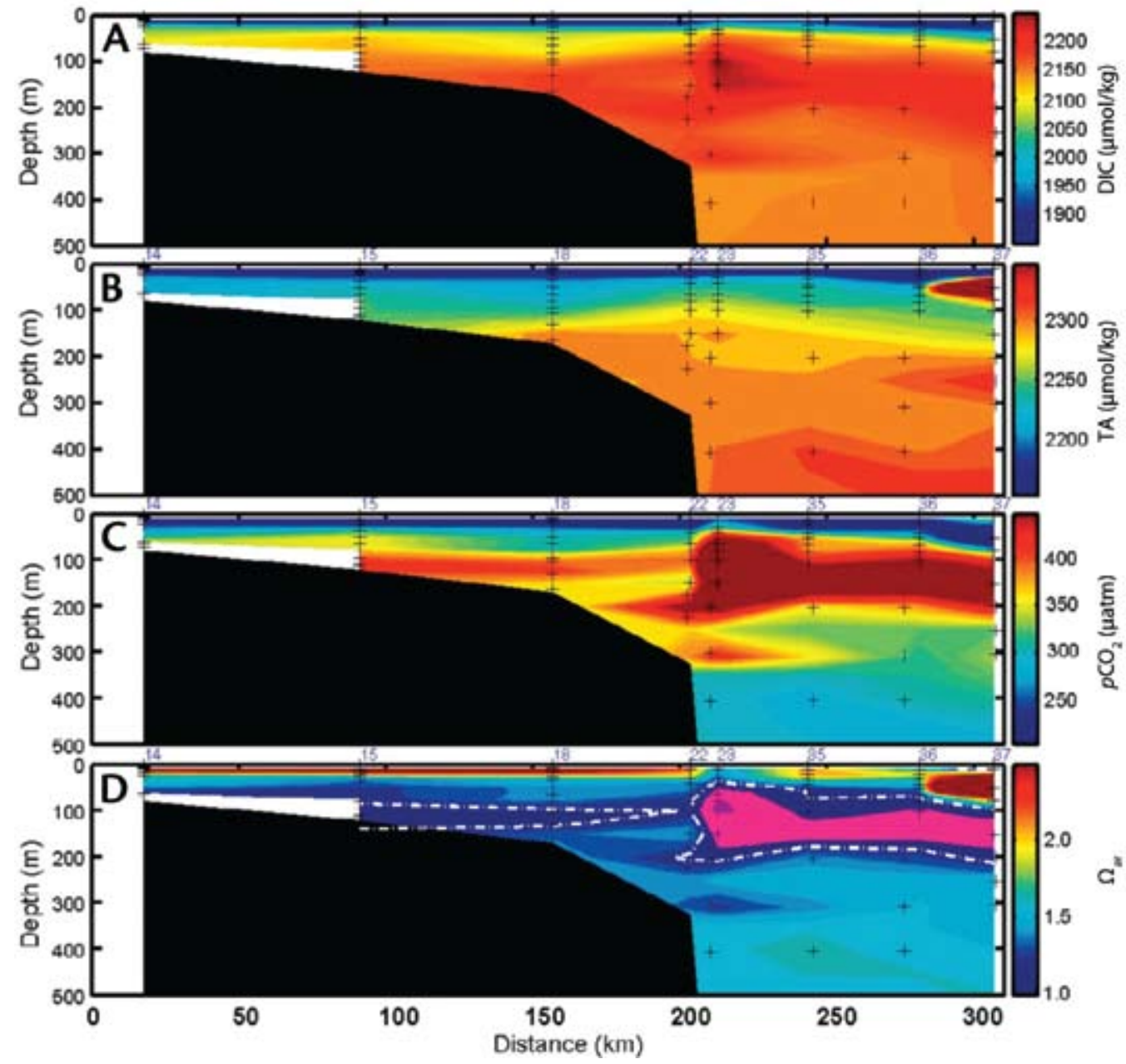

Figure 1. Representative section of (A) dissolved inorganic carbon (DIC; $\mu \mathrm{mol} \mathrm{kg}{ }^{-1}$ ), (B) total alkalinity (TA; $\left.\mu \mathrm{mol} \mathrm{kg}{ }^{-1}\right),(\mathrm{C}) p \mathrm{CO}_{2}$ ( $\mu$ atm), and (D) aragonite saturation state $\left(\Omega_{\mathrm{ar}}\right)$ across the Chukchi Sea shelf into the deep Canada Basin of the Arctic Ocean at Barrow Canyon, summer 2002. Note that the pink color in the bottom panel represents regions of aragonite undersaturation. Adapted from Bates et al. (2009) to become undersaturated with respect to aragonite throughout the year. With rising atmospheric $\mathrm{CO}_{2}$, the spatial and temporal extent of aragonite undersaturation in the Arctic Ocean continues to grow until the entire water column becomes undersaturated with respect to aragonite when atmospheric $\mathrm{CO}_{2}$ reaches 765 ppm.

\section{The Bering Sea}

Recent observations show that the eastern shelf of the Bering Sea is exhibiting a phenomenon involving phytoplankton productivity and $\mathrm{CaCO}_{3}$ saturation state similar to that observed in the Chukchi Sea (recent work of author Mathis and colleagues). Between spring (April) and summer (July) occupations over the shelf, the remineralization of exported organic matter in the bottom waters forced $\Omega_{\mathrm{ar}}<1$ (Figure 2), while primary productivity resulted in decreased $p \mathrm{CO}_{2}$ and increased aragonite saturation in the surface ocean. Unlike the Chukchi Sea, however, several observations in spring showed aragonite undersaturation from the surface to the bottom at inshore stations near the outflows of the Yukon and Kuskokwim rivers, both of which contain a high ratio of $p \mathrm{CO}_{2}$ to total alkalinity (e.g., Striegl et al., 2007). Because observations are limited, the duration of subsurface $\Omega_{\mathrm{ar}}$ suppression over the eastern Bering Sea shelf currently cannot be constrained, but it is likely to persist longer in the future due to increases in productivity, atmospheric $\mathrm{CO}_{2}$ concentrations, and river runoff.

\section{The Gulf of Alaska}

The Gulf of Alaska in the subarctic Pacific is a direct extension of the North Pacific and will be impacted by enhanced ocean acidification over the next decade. This region is vitally important to the coastal economy of Alaska, particularly because of its salmon fishery. Observations by author Mathis and colleagues from inside Resurrection Bay (RB) to the outer shelf 


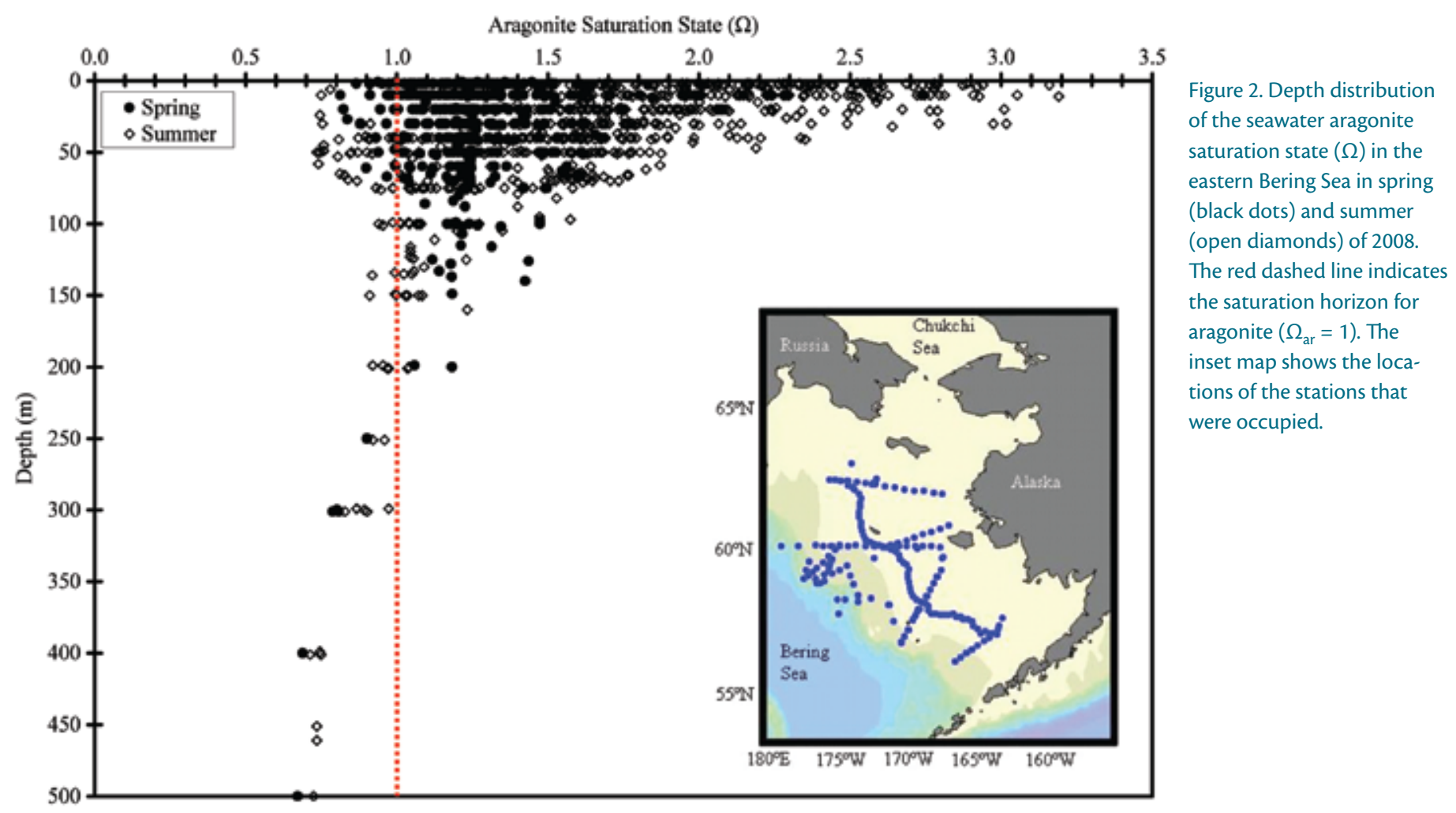

break (Figure 3) in September 2008

showed that bottom waters inside the bay and along the inner shelf were undersaturated with respect to aragonite, and, over the shelf break, the aragonite saturation horizon outcropped to $<150 \mathrm{~m}$ from the surface. Aragonite undersaturation in bottom waters over the inner shelf was not found in May 2008, and the observed undersaturation in September may be the result of remineralization of organic matter at depth coupled with upwelling of deep water onto the shelf.

\section{IMPACTS ON BIOTA}

\section{AND ECOSYSTEMS}

Some of the richest and most heavily exploited fishing areas in the world are located in high-latitude seas. The southeastern Bering Sea shelf (inset in Figure 2) sustains more than half of the total US fish landings annually through massive pollock, salmon, and crab catches (Grebmeier et al., 2006). In the Southern Ocean, the major fisheries are krill and Patagonian toothfish (Antarctic cod). Cold-water corals, including those near the Aleutian Islands, Alaska, and deep-water, emergent coral communities in the fjords of southern Chile, support high biodiversity (Guinotte and Fabry, 2008). High-latitude organisms are not as well studied as those living in lower latitudes, however. Although a few investigations have begun recently, the effects of ocean acidification on polar and subpolar marine life remain largely unexamined.

Polar marine invertebrates often exhibit low metabolic rates (Bluhm et al., 1998; Peck and Conway, 2000) and very slow development and growth (Pearse et al., 1991; Arntz et al., 1994; Coyle and Highsmith, 1994) when compared with similar taxa at mid or low latitudes. Because of their prolonged life histories, fewer generations will have opportunities for successful acclimation or adaptation to seawater that will become progressively elevated in dissolved $\mathrm{CO}_{2}$ and bicarbonate ion concentration and reduced in $\mathrm{pH}$, carbonate ion concentration, and $\mathrm{CaCO}_{3}$ saturation state. Although many physiological processes in diverse organisms may be affected by rising ocean acidity, the declining aragonite and calcite saturation states of surface waters - and establishment of corrosive conditions in some regionsmay particularly impact high-latitude planktonic and benthic calcifiers.

\section{Planktonic Communities}

Although present throughout the world ocean, thecosomatous pteropods (shelled plantkonic snails) can reach densities of thousands of individuals per cubic meter in high latitudes where they are prey for a variety of zooplankton and fish 
(e.g., pollock, salmon, cod, mackerel). In the subarctic Pacific, pteropods can be important prey of juvenile pink salmon, accounting in some years for $>60 \%$ by weight of their diet (Armstrong et al., 2005). When exposed to the level of aragonite undersaturation expected to occur by the year 2100 , one pteropod species (Clio pyramidata) showed net shell dissolution within 48 hours (Orr et al., 2005). In the Gulf of Alaska, the shoaling aragonite saturation horizon coupled with the region's deep winter mixing may bring subsurface waters that are corrosive to aragonite to the upper ocean where they could adversely affect pteropod populations. Similarly, the projected reductions in the aragonite saturation state of Ross Sea surface waters may cause dissolution of the thin shells of the abundant pteropod Limacina helicina antarctica (Figure 4A, cover of this issue), unless this species has mechanisms to prevent net shell dissolution (recent work of author Fabry and colleagues). If high-latitude thecosomatous pteropods cannot adapt to living in seawater that is expected to become corrosive to aragonite throughout the year as early as mid century (Orr et al., 2005; Steinacher et al., 2009), their ranges will likely first contract to shallower depths and then, provided they can survive warmer temperatures and successfully compete with other species, to lower latitudes that have higher carbonate ion concentrations.

Other planktonic calcifiers may be impacted by changing carbonate chemistry at high latitudes. In a comparison between shell weights of the foraminifer Globigerina bulloides collected from sediments traps in the subantarctic Southern Ocean with shell weights preserved in underlying Holocene sediments, Moy et al. (2009) reported that modern shell weights are about $30 \%$ lower than those from sediments and suggest that these results are consistent with those expected from ocean acidification. If the production of foraminifer calcite decreases in some high-latitude regions where foraminifers are currently abundant (e.g., subarctic Pacific), the potential for foraminiferal tests to act as ballast in the transport of organic carbon to the deep sea would be similarly reduced (Schiebel, 2002).
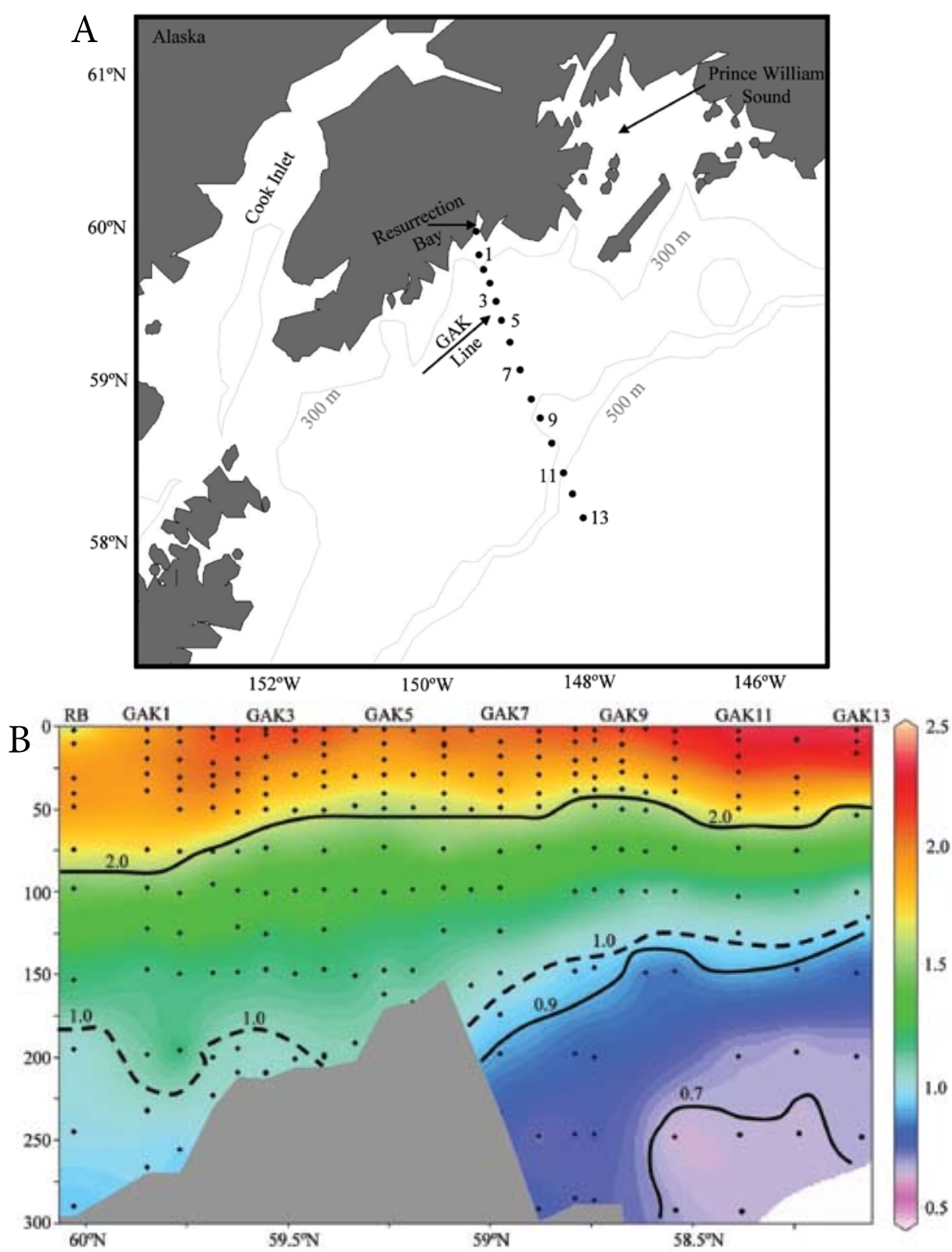

Figure 3. (A) Map of the Gulf of Alaska showing the locations of the stations occupied. (B) Seawater aragonite saturation state $(\Omega)$ in September 2008 along the Gulf of Alaska (GAK) line. The dashed line indicates the depth of the saturation horizon for aragonite $\left(\Omega_{\mathrm{ar}}=1\right)$. 
Figure 4. Photographs of examples of weakly calcified Antarctic marine invertebrates. (Top) Pteropod Limacina helicina antarctica. (Middle) Limpets with encrusting coralline red algae growing on shells. (Bottom) Brachiopods. Photo credits: V. Fabry (top), D. Martin (middle and bottom)
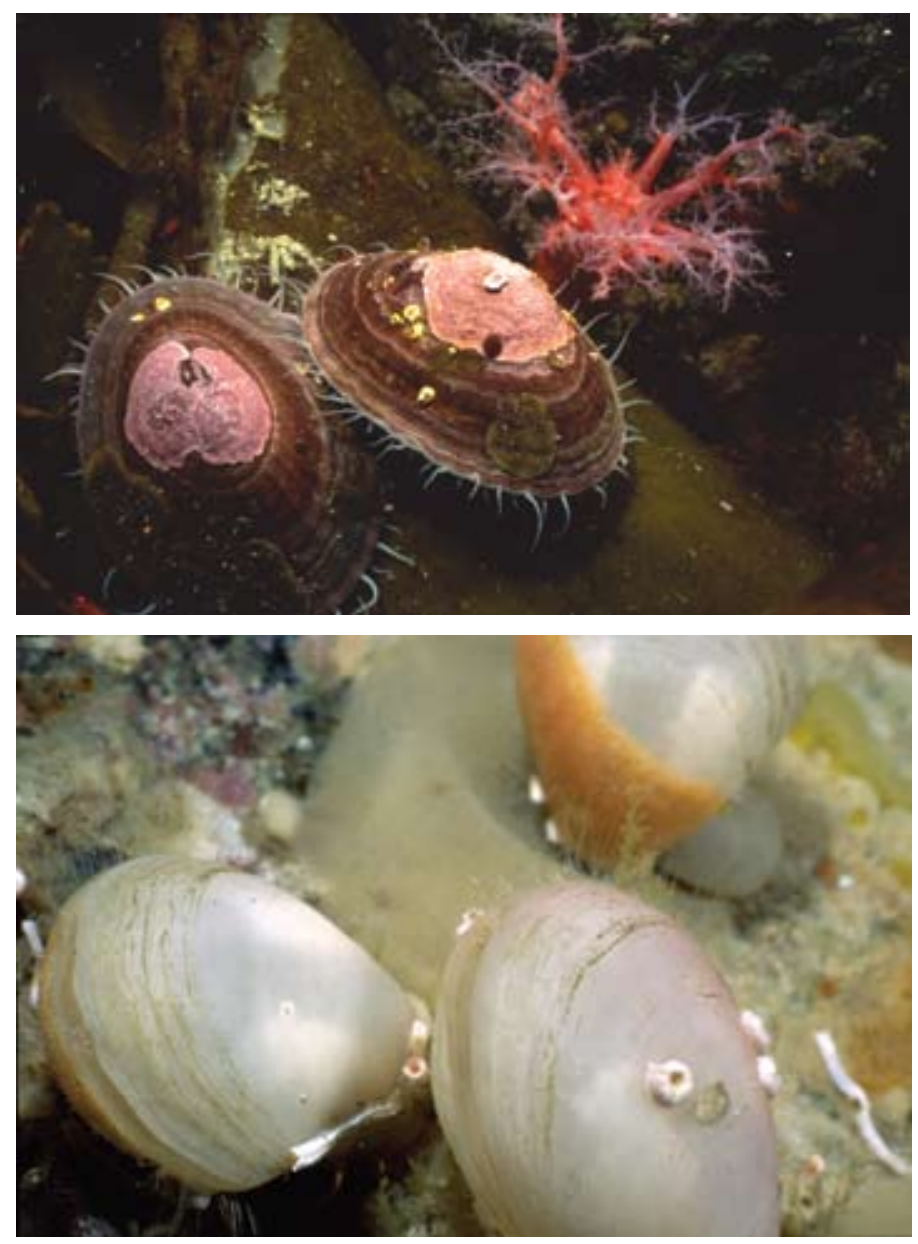

\section{Benthic Communities}

High-latitude marine benthic communities of the Southern and Northern hemispheres differ, reflecting different geological and evolutionary histories. The Antarctic continent's landmass is the size of China and India combined, and it is surrounded by the Southern Ocean.
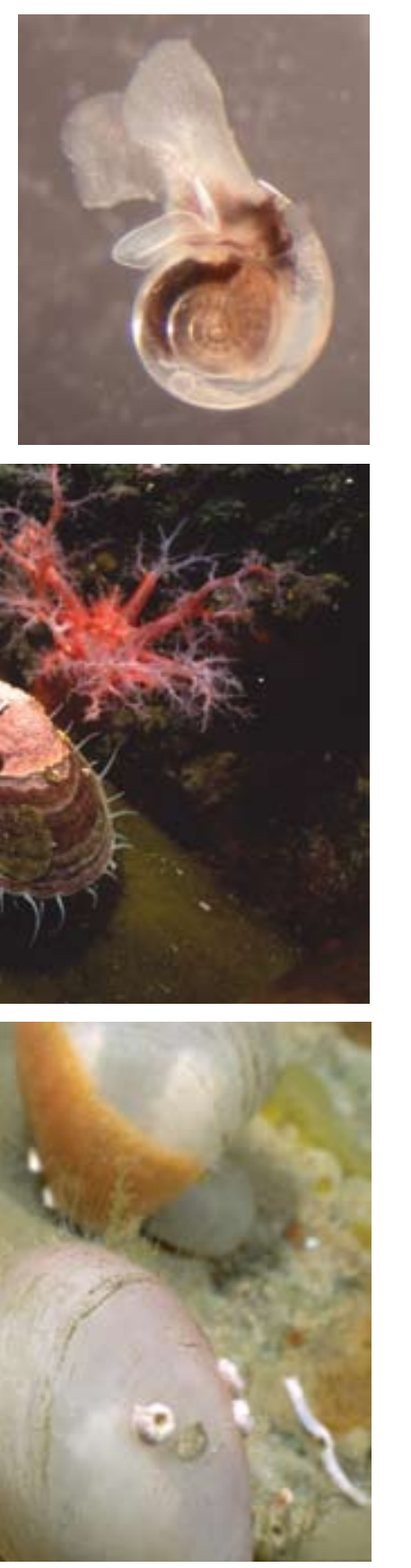
seawater temperatures that occur in nearshore Antarctica. The lack of crushing predators may have contributed to the evolution of the thin, weakly calcified shells that typify marine invertebrates of Antarctic benthic communities (Aronson et al., 2007; McClintock et al., 2008; Figure 4). Another contributing factor to their poor calcification may be the inverse correlation between seawater temperature and the solubility of calcium carbonate, a relationship that makes shell calcification more demanding at low temperature. Recently, McClintock et al. (2009) demonstrated that post-mortem shells of weakly calcified Antarctic bivalves and a brachiopod suffer significant dissolution (loss of mass) after only 35 days when held at $4^{\circ} \mathrm{C}$ in seawater at a $\mathrm{pH}$ of 7.4. By day 56, severe erosion of the outer shell surface layers was detected, exposing the structural prisms within the shell architecture (Figure 5).

Rich and diverse benthic communities also occur in high-latitude regions of the Northern Hemisphere (Carey, 1991), including the Bering Sea shelf, which supports some of the highest benthic faunal biomass in the world (Grebmeier et al., 2006). An example of a group that may be at risk from ocean acidification is the bivalves that dominate the infauna of sediments of the northern Bering Sea, just south of St. Lawrence Island. This area is influenced by a winter polynya (an open area in ice-covered seas) that forms south of St. Lawrence Island when the winds blow from the north. The cold, brine-rich waters that descend to the benthos form the low-temperature $\left(<-1^{\circ} \mathrm{C}\right)$ cold pool in late winter that becomes enriched with $\mathrm{CO}_{2}$ owing to high carbon recycling in the sediments and the large populations of bioturbating organisms (Grebmeier and Barry, 2007). The three main types of clams in the region include: Nuculana radiata (Nuculanidae), Macoma calcarea and
M. moesta (Tellinidae), and Nuculidae (Nucula belloti) (Figure 6). The diving spectacled eider, a threatened species, consumes tellinid bivalves (white, lower left and upper right corners, Figure 6A) that live in sediments, but now also preys on a specific size class of nuculanid bivalve prey (Lovvorn et al., 2009). The thin-shelled tellinid bivalves have been decreasing in number over the past few decades, and birds now focus their feeding on $N$. radiata (Figure 6B), a thicker-shelled clam. All of these bivalves, the prey base for the spectacled eider, currently live in a very cold environment $\left(<-1.5^{\circ} \mathrm{C}\right)$ and thus have high susceptibility for potential impact by ocean acidification. The northern Bering and Chukchi seas support extremely high biomass of key calcifying prey organisms for higher trophic predators, such as diving seaducks, bearded seals, gray whales, and walruses. In addition, snow crab (Opilio spp.) populations
A

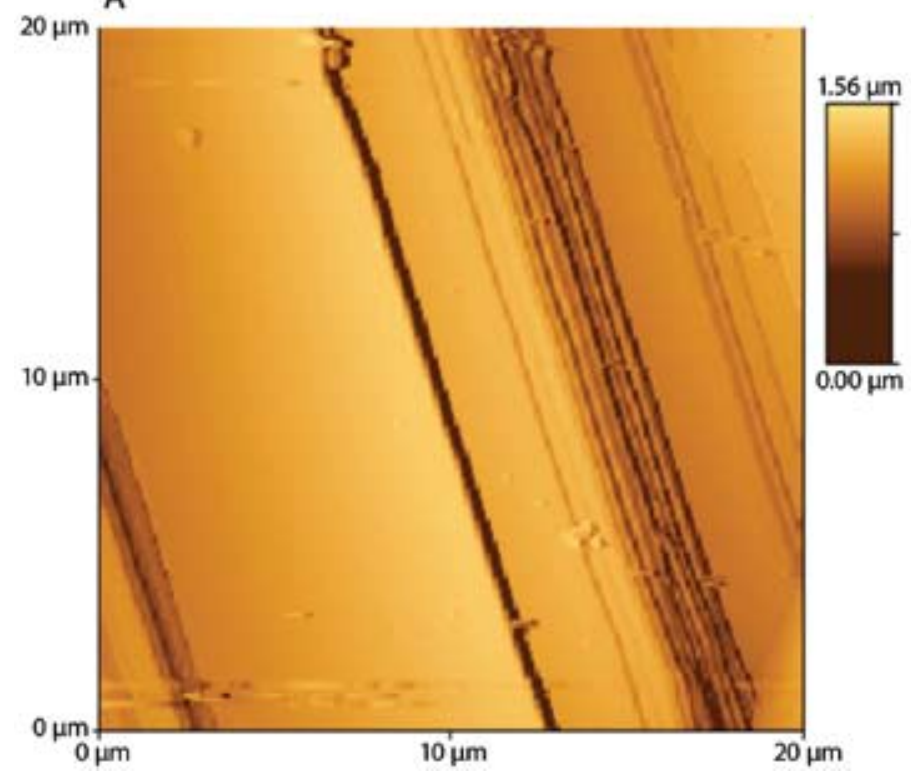

B

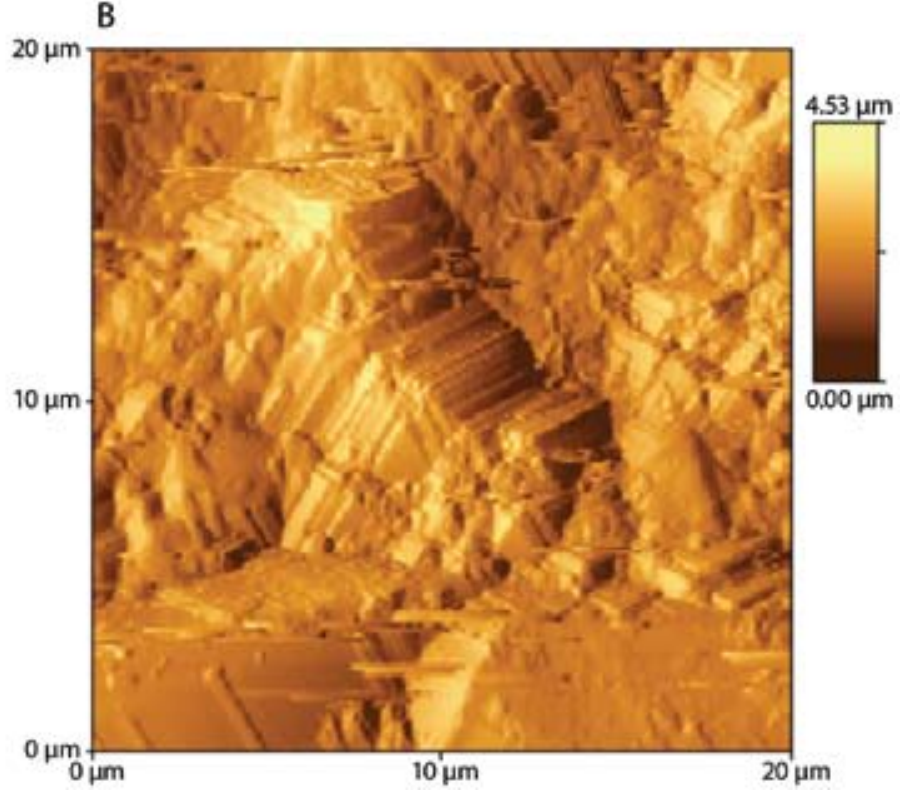

Figure 5. Atomic force micrographs of the surfaces of shells of the Antarctic bivalve Yoldia eightsi exposed for 56 days to (A) control seawater at pH 8.2 and (B) acidified seawater at pH 7.4. Calcium carbonate prisms indicating dissolution are visible in the acidified shell (McClintock et al., 2009). 

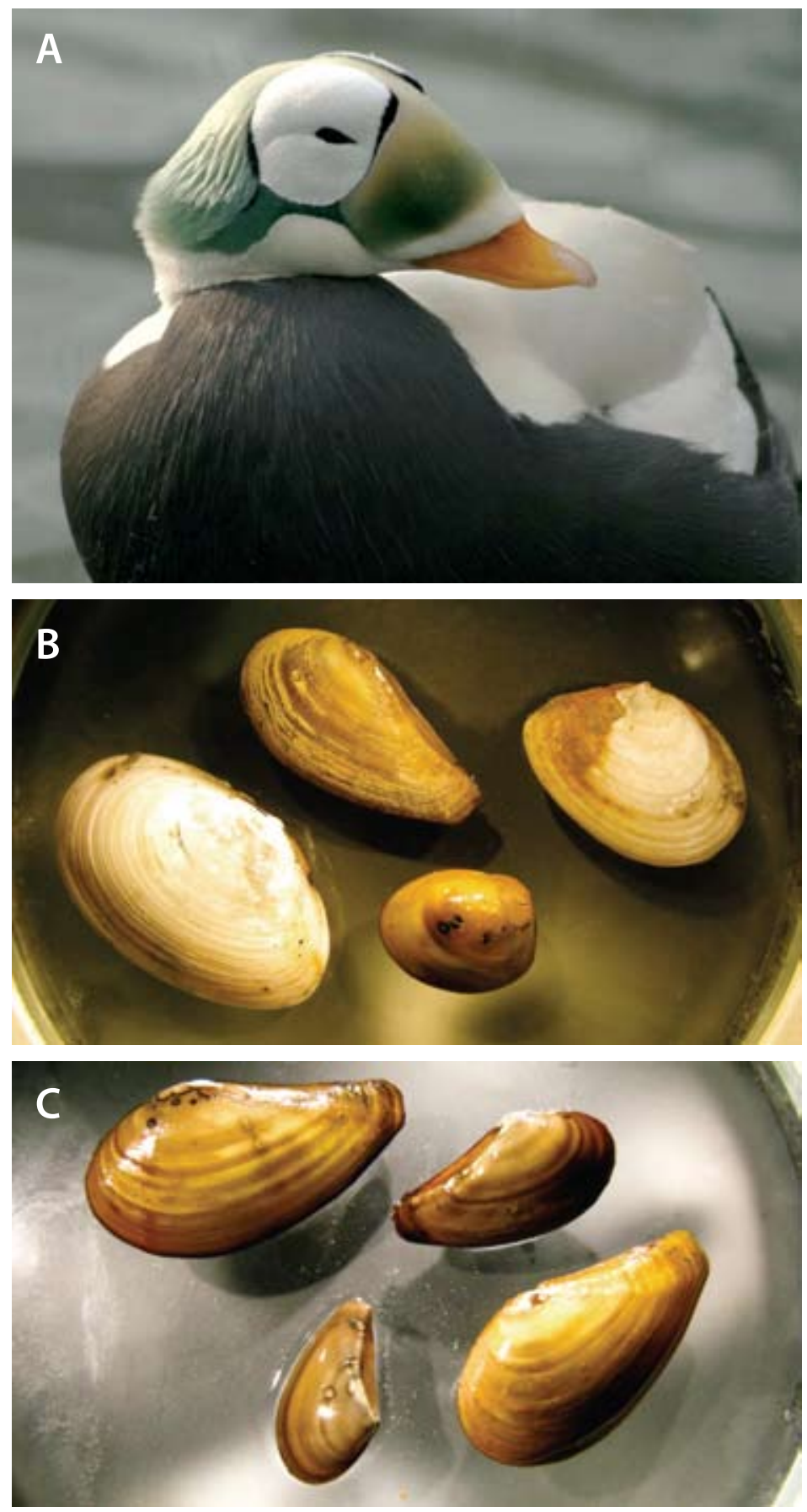

Figure 6. Arctic bivalves consumed by spectacled eiders (A). (B) Thin-shelled tellinid clams appear white in lower left and upper right corners. (C) Clam Nuculana radiata with thicker shells. Photo credits: L. Whitehouse (A), A. Trites (B and C)

are increasing in the north (Grebmeier et al., 2006, Cui et al., 2009), whereas ampeliscid amphipods that are the prey of gray whales are declining (Moore et al., 2003; Coyle et al., 2007). Whether these crustaceans will be impacted by increasing $\mathrm{CO}_{2}$ levels in bottom waters is unknown. Other taxa potentially at risk from ocean acidification are solitary corals and basket stars that live in the fast current areas in Arctic regions and that contribute to the biodiversity of the northern marine systems.

\section{OCEAN ACIDIFICATION AND OTHER ENVIRONMENTAL AND BIOTIC STRESSORS}

Warming temperatures associated with anthropogenic climate change are driving major ecological changes in polar regions of both hemispheres. With a transition from arctic to subarctic conditions in the northern Bering Sea, marine mammal distributions have shifted poleward, coincident with a reduction in their benthic prey, and accompanied by an increase in pelagic fish (Grebmeier et al., 2006). There are also indications of a penetration of Pacific benthic clams into the Chukchi Sea (Sirenko and Gagaev, 2007) and movement of Pacific zooplankton species into the Beaufort Sea (Nelson et al., 2009). Seasonal air temperatures recorded over the past 60 years indicate that the western Antarctic Peninsula is now the most rapidly warming region on Earth (Clarke et al., 2007; Ducklow et al., 2007; McClintock et al., 2008). The west coast of the northern Antarctic Peninsula is changing from a cold, dry polar climate to a warmer, humid subantarctic climate, with reduced sea ice and productivity displacing ice-dependent species such as krill and Adelie penguins poleward (Montes-Hugo et al., 2009). Warming sea temperatures may allow shell-crushing, deep-water king crabs to invade the continental shelves surrounding Antarctica (Thatje et al., 2005). Since the Eocene (33 million years ago), constant, very low seawater temperatures have precluded crabs from invading Antarctic 
seas, in large part due to the narcotizing effects of magnesium in their hemolymph at very cold temperature. As warming seawater temperatures remove this physiological barrier, king crabs are beginning to migrate up the western Antarctic continental slope (Thatje et al., 2005; Figure 7). If king crabs successfully invade the continental shelf, the thinly calcified shells and $\mathrm{CaCO}_{3}$ skeletons of Antarctic invertebrates such as molluscs and echinoderms would be readily crushed by the powerful claws of these benthic predators, with substantial implications for biodiversity and structure of these benthic communities (Aronson et al., 2007). Any weakening of invertebrate shells owing to ocean acidification would likely render them even more vulnerable to these crushing predators. Over the next decades, these trends of rising seawater temperatures and invasive fauna coupled with progressive ocean acidity are expected to increasingly influence both planktonic and benthic marine communities of Antarctica and the Arctic.

\section{FUTURE RESEARCH}

Because surface waters in high latitudes will be the first ocean regions to become persistently undersaturated with respect to aragonite as a result of human activities, polar and subpolar seas are a bellwether for global ocean acidification. Changes in seawater $\mathrm{CO}_{2}$ chemistry have already been detected, and are expected to intensify within decades. The rapid rates of change now in progress at high latitudes emphasize the urgent need to accelerate efforts in ocean acidity monitoring and research.

In high-latitude seas of the Northern and Southern hemispheres, seawater inorganic carbon measurements with increased spatial and temporal resolution are critical. In conjunction with these seawater chemistry observations, high-quality measurements of the abundances and depth distributions of key planktonic and benthic organisms and their rates of calcification, growth, and metabolism are needed now and with appropriate sampling effort to differentiate natural variability from anthropogenic-induced changes that may occur within the next 10-20 years. For different life stages of key species, manipulative laboratory experiments are needed to investigate organisms' calcification and dissolution responses, identify physiological indices useful in predicting $\mathrm{CO}_{2}$ tolerance, determine the costs of acid-base regulation, and quantify sensitive energetic processes such as skeletal and somatic tissue growth, reproduction, and metabolism. These manipulative studies will need to consider that while compensatory calcification may occur in response to acidification in some species, it may also come at an appreciable (or even fatal) cost to the organism (e.g., Wood et al., 2008, McDonald et al., 2009). Therefore, measurement of multiple physiological processes is desirable. To better understand these compensatory processes and their trade-offs, mechanistic studies of the regulation of calcification with ocean acidification are now needed, including functional genomic and physiological studies to investigate the interplay of $\mathrm{CO}_{2}$ and key regulatory enzymes such as carbonic anhydrase (Tambutté et al., 2007; Hofmann et al., 2008). Target species for investigation in high-latitude

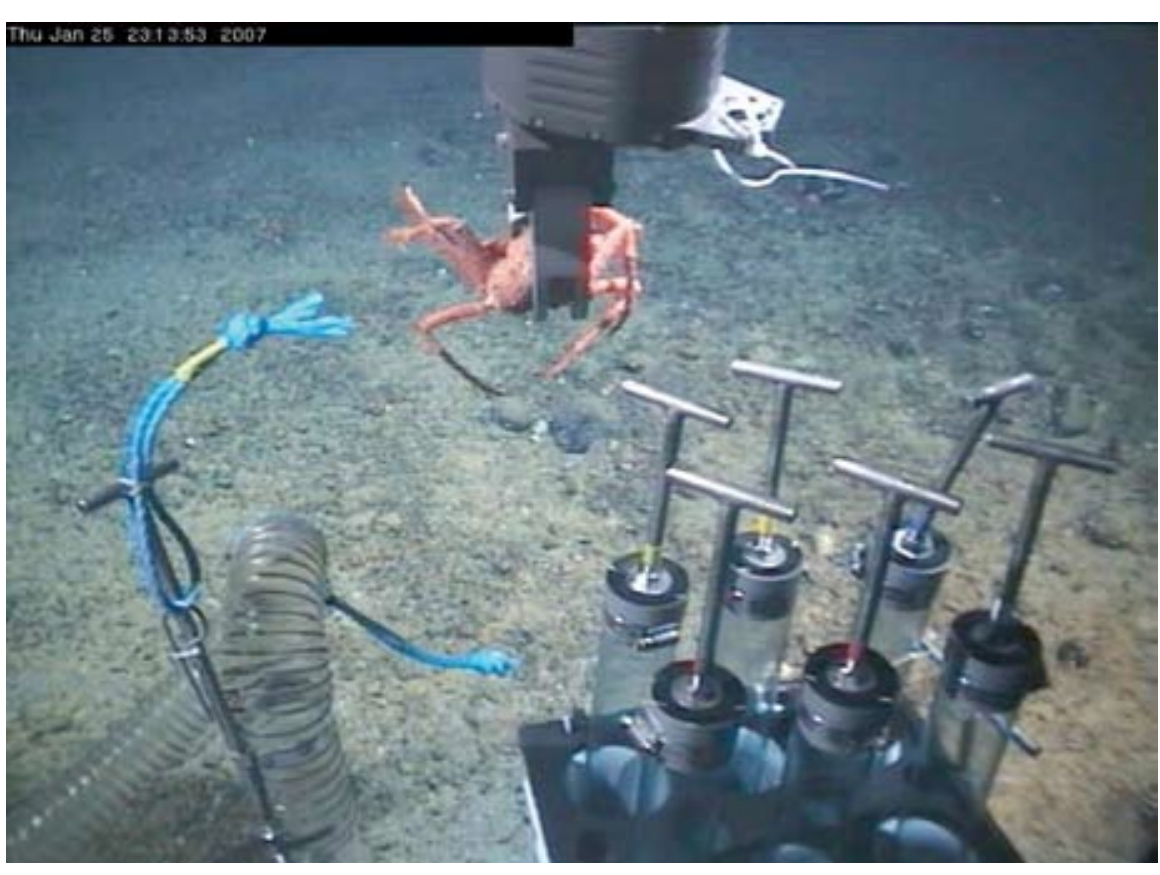

Figure 7. One of 13 juvenile and adult individuals of the lithodid king crab Paralomis birsteini discovered on the Antarctic continental slope using the remotely operated vehicle Isis deployed from R/V James Clark Ross (JCR 166) in January 2007 (Thatje et al., 2008). Bellingshausen Sea, Antarctica (1123-m depth). Photo credit: Sven Thatje 
regions include thecosomatous pteropods, foraminifers, coccolithophores, epi-pelagic squids, cold-water corals, calcareous algae, and larval stages and adults of commercially and ecologically important benthic marine invertebrates such as bivalves, sea urchins, crabs, and lobsters. Experimental design should consider the potential interaction of increased ocean acidification with warmer seawater temperature.
Admundsen, and Ross seas.

Similarly, a long-term monitoring and investigative program is needed in the marine Arctic regions where both bivalve and crab populations are transiting northward from the subarctic regions. Many of these areas have high pteropod populations that influence pelagicbenthic coupling processes critical to the marine systems of this region. Time series, latitudinally placed transect lines

JBM also acknowledges support provided by an Endowed Professorship at the University of Alabama at Birmingham.

\section{REFERENCES}

Armstrong, J.L., J.L. Boldt, A.D. Cross, J.J. Moss, N.D. Davis, K.W. Myers, R.V. Walker, D.A. Beauchamp, and L.J. Haldorson. 2005. Distribution, size, and interannual, seasonal and diel food habits of northern Gulf of Alaska juvenile pink salmon, Oncorhynchus gorbuscha. Deep-Sea Research Part II 52:247-265.

Arntz, W.E., T. Brey, and V.A. Gallardo. 1994. Antarctic zoobenthos. Oceanography and Marine Biology 32:251-303.

Aronson, R., S. Thatje, A. Clarke, L.S. Peck, D.B. Blake, C.D. Wilga, and B.A. Seibel. 2007. Climate change and invasibility of the Antarctic benthos. Annual Review of Ecology, Evolution, and Systematics 38:129-154.

RISING SEAWATER TEMPERATURES AND INVASIVE FAUNA COUPLED WITH PROGRESSIVE OCEAN ACIDITY ARE EXPECTED TO INCREASINGLY INFLUENCE BOTH PLANKTONIC AND BENTHIC MARINE COMMUNITIES OF ANTARCTICA AND THE ARCTIC.

In the Southern Ocean, long-term studies are needed to track the movements and evaluate the consequences for benthic communities of invasive king crabs currently moving up the Antarctic slope and onto the coastal shelf. Such efforts might build on a 2010 joint United States-Swedish research program (supported primarily by the US National Science Foundation) that will use the Swedish icebreaker Oden and the US icebreaker R/V Nathaniel B. Palmer in tandem to conduct autonomous underwater vehicle video transect surveys, benthic and epibenthic trawls, and plankton sampling to evaluate patterns of larval, juvenile, and adult king crab occurrence in shelf-slope transition regions along the Antarctic Peninsula and in the Bellingshausen, with standard hydrographic, nutrient, and inorganic carbon measurements coincident with lower trophic level standing stocks and rate measurements, as well as process studies tied to specific marine predators, are essential to evaluate the ongoing changes in marine animal population distributions and community composition in the shelf and shelf-slope regions of the Pacific Arctic sector.

\section{ACKNOWLEDGEMENTS}

We thank the Antarctic Organisms and Ecology Program, Chemical Oceanography Program, Biological Oceanography Program, and Division of Arctic Sciences of the National Science Foundation (NSF), as well as the US Minerals Management Service for research support on ocean acidification.
Bates, N.R., and J.T. Mathis. 2009. The Arctic Ocean marine carbon cycle: Evaluation of air-sea $\mathrm{CO}_{2}$ exchanges, ocean acidification impacts and potential feedbacks. Biogeosciences 6:2,433-2,459.

Bates, N.R., J.T. Mathis, and L.W. Cooper. 2009. Ocean acidification and biologically induced seasonality of carbonate mineral saturation states in the western Arctic Ocean. Journal of Geophysical Research 114, C11007, doi:10.1029/2008JC004862.

Bates, N.R., S.B. Moran, D.A. Hansell, and J.M. Mathis. 2006. An increasing $\mathrm{CO}_{2}$ sink in the Arctic Ocean due to sea-ice loss? Geophysical Research Letters 33, L23609, doi:10.1029/2006GL027028.

Bluhm, B.A., D. Piepenburg, and K. von Juterzenka. 1998. Distribution, standing stock, growth, mortality and production of Strongylocentrotus pallidus (Echinodermata: Echinoidea) in the northern Barents Sea. Polar Biology 20:325-334.

Carey, A.G., Jr. 1991. Ecology of the North American Arctic continental shelf benthos: A review. Continental Shelf Research 11:865-883.

Clarke, A., and N.M. Johnston. 2003. Antarctic marine benthic diversity. Oceanographic Marine Biology 42:47-114.

Clarke, A., E.J. Murphy, M.P. Meredith, J.C. King, L.S. Peck, D.K.A. Barnes, and R.C. Smith. 2007. Climate change and the marine ecosystem of the western Antarctic Peninsula. Philosophical Transactions of the Royal Society B 362:149-166.

Coyle, K.O., B. Bluhm, B. Konar, A. Blanchard, and R.C. Highsmith. 2007. Amphipod prey of gray whales in the northern Bering Sea: Comparison of biomass and distribution between the 1980s and 2002-2003. Deep-Sea Research Part II 54:2,906-2,918.

Coyle, K.O., and R.C. Highsmith. 1994. Benthic amphipod community in the northern Bering Sea: Analysis of potential structuring mechanisms. Marine Ecology Progress Series 107:233-244. 
Cui, X., J.M. Grebmeier, L.W. Cooper, J.R. Lovvorn, C.A. North, and J.M. Kolts. 2009. Spatial distributions of groundfish in the northern Bering Sea in relation to environmental variation. Marine Ecology Progress Series 19(6):1,596-1,613.

Dayton, P.K., B.J. Mordida, and F. Bacon. 1994. Polar marine communities. American Zoologist 34:90-99.

Dayton, P.K., G.A. Robilliard, R.T. Paine, and L.B. Dayton. 1974. Biological accommodation in the benthic community at McMurdo Sound, Antarctica. Ecological Monographs 44:105-128.

Ducklow, H.W., K. Baker, D.G. Martinson, L.B. Quetin, R.M. Ross, R.C. Smith, E. Satmmerjohn, M. Vernet, and W. Fraser. 2007. Marine pelagic ecosystems: The West Antarctic Peninsula. Philosophical Transactions of the Royal Society B 362:67-94.

Fabry, V.J., B.A. Seibel, R.A. Feely, and J.C. Orr. 2008. Impacts of ocean acidification on marine fauna and ecosystem processes. ICES Journal of Marine Sciences 65:414-432.

Feeley, R.A., S.C. Doney, and S.R. Cooley. 2009. Ocean acidification: Present conditions and future changes in a high- $\mathrm{CO}_{2}$ world. Oceanography 22(4):36-47.

Feely, R.A., C.L. Sabine, K. Lee, W. Berelson, J. Kleypas, V.J. Fabry, and F.J. Millero. 2004. Impact of anthropogenic $\mathrm{CO}_{2}$ on the $\mathrm{CaCO}_{3}$ system in the oceans. Science 305:362-366.

Grebmeier, J.M., and J.P. Barry. 1991. The influence of oceanographic processes on pelagic-benthic coupling in polar regions: A benthic perspective. Journal of Marine Systems 2:495-518.

Grebmeier, J.M., and J.P. Barry. 2007. Benthic processes in polynyas. Pp. 363-390 in Polynyas: Windows to the World. W.O. Smith Jr. and D.G. Barber, eds, Elsevier Oceanography Series, Volume 74 .

Grebmeier, J.M., J.E. Overland, S.E. Moore, E.V. Farley, E.C. Carmack, L.W. Cooper, K.E. Frey, J.H. Helle, F.A. McLaughlin, and S.L. McNutt. 2006. A major ecosystem shift in the northern Bering Sea. Science 311:1,461-1,464.

Guinotte, J.M., and V.J. Fabry. 2008. Ocean acidification and its potential effects on marine ecosystems. Annals of the New York Academy of Sciences 1134:320-342, doi:/10.1196/annal.1439.013.

Hofmann, G.E., M.J. O’Donnell, and A.E. Todgham. 2008. Using functional genomics to explore the effects of ocean acidification on calcifying marine organisms. Marine Ecology Progress Series 373:219-225.

Key, R.M.A., A. Kozyr, C.L. Sabine, K. Lee, R. Wanninkhof, J.L. Bullister, R.A. Feely, F.J. Millero, C. Mordy, and T.-H. Peng. 2004. A global ocean carbon climatology: Results from the Global Data Analysis Project (GLODAP). Global Biogeochemical Cycles 18, GB4031, doi:10.1029/2004GB002247.
Khatiwala, S., F. Primeau, and T. Hall. 2009. Reconstruction of the history of anthropogenic $\mathrm{CO}_{2}$ concentrations in the ocean. Nature 462:346-349.

Lovvorn, J.R., J.M. Grebmeier, L.W. Cooper, J.K. Bump, and S.E. Richman. 2009. Modeling marine protected areas for threatened eiders in a climatically changing Bering Sea. Ecological Applications 19(6):1,596-1,613, doi:10.1890/08-1193.1.

McClintock, J.B., R.A. Angus, M.R. McDonald, C.D. Amsler, S.A. Catledge, and Y.K. Vohra. 2009. Rapid dissolution of shells of weakly calcified Antarctic benthic macroorganisms indicates high vulnerability to ocean acidification. Antarctic Science 21:449-456.

McClintock, J., H. Ducklow, and B. Fraser. 2008. Ecological impacts of climate change on the Antarctic Peninsula. American Scientist 96:302-310.

McDonald, M.R., J.B. McClintock, C.D. Amsler, D. Rittschof, R.A. Angus, B. Orihuela, and K. Lutostanski. 2009. Effects of ocean acidification over the life history of the barnacle Amphibalanus amphitrite. Marine Ecology Progress Series 385:179-187.

McNeil, B.I., and R.J. Matear. 2008. Southern Ocean acidification: A tipping point at $450-\mathrm{ppm}$ atmospheric $\mathrm{CO}_{2}$. Proceedings of the National Academy of Sciences of the United States of America 105:18,860-18,864.

Montes-Hugo, M., S.C. Doney, H.W. Ducklow, W. Fraser, D. Martinson, S.E. Stammerjohn, and O. Schofield. 2009. Recent changes in phytoplankton communities associated with rapid regional climate change along the western Antarctic Peninsula. Science 323:1,470-1,473, doi:10.1126/science.1164533.

Moore, S.E., J.M. Grebmeier, and J.R. Davies. 2003. Gray whale distribution relative to forage habitat in the northern Bering Sea: Current conditions and retrospective summary. Canadian Journal of Zoology 81(4):734-742, doi:10.1139/z03-043.

Moy, A.D., W.R. Howard, S.G. Bray, and T.W. Trull. 2009. Reduced calcification in modern Southern Ocean planktonic foraminifera. Nature Geoscience 2:276-280.

Nelson, R.J., E.C. Carmack, F.A. McLaughlin, and G.A. Cooper. 2009. Penetration of Pacific zooplankton into the western Arctic Ocean tracked with molecular population genetics. Marine Ecology Progress Series 381:129-138.

Orr, J.C., L.G. Anderson, N.R. Bates, L. Bopp, V.J. Fabry, E.P. Jones, and D. Swingedouw. 2006. Arctic Ocean acidification. Eos, Transactions, American Geophysical Union 87(36), Ocean Sciences Meeting Supplement, Abstract OS14B-01.

Orr, J.C., V.J. Fabry, D. Aumont, L. Bopp, S.C. Doney, R.A. Feely, A. Gnanadesikan, N. Gruber, A. Ishinda, F. Jacobs, and others. 2005. Anthropogenic ocean acidification over the twenty-first century and its impacts on calcifying organisms. Nature 437:481-486.
Pearse, J.S., B. McClintock, and I. Bosch. 1991. Reproduction of Antarctic benthic marine invertebrates: Tempos, modes and timing. American Zoologist 31:65-80.

Peck, L.S., and L.Z. Conway. 2000. The myth of metabolic cold adaptation: Oxygen consumption in stenothermal Antarctic bivalve molluscs. Pp. 441-450 in Evolutionary Biology of the Bivalvia. E. Harper, J.D. Taylor, J.A. Crame, eds, Geological Society of London Special Publication no. 177, The Geological Society Publishing House, Bath, UK.

Sabine, C.L., R.A. Feely, N. Gruber, R.M. Key, K. Lee, J.L. Bullister, R.Wanninkhof, C.S. Wong, D.W.R. Wallace, B. Tilbrook, and others. 2004. The oceanic sink for anthropogenic $\mathrm{CO}_{2}$. Science 305:367-371, doi:10.1126/science.1097403.

Schiebel, R. 2002. Planktonic foraminiferal sedimentation and the marine calcite budget. Global Biogeochemical Cycles 16(4), doi:10.1029/2001GB1459.

Sirenko, B.I., and S. Yu Gagaev. 2007. Unusual abundance of macrobenthos and biological invasions in the Chukchi Sea. Russian Journal of Marine Biology 33:355-364.

Steinacher, M., F. Joos, T.L. Frolicher, G.-K. Plattner, and S.C. Doney. 2009. Imminent ocean acidification in the Arctic projected with the NCAR global climate carbon cycle-climate model. Biogeosciences 6:515-533.

Striegl, R.G., M.M. Dornblaser, G.R. Aiken, W.R. Wickland, and P.A. Raymond. 2007. Carbon export and cycling by the Yukon, Tanana, and Porcupine rivers, Alaska, 2001-2005. Water Resources Research 43, WO2411, doi:10.1029/ 2006WR005201.

Tambutté, S., E. Tambutté, D. Zoccola, N. Caminiti, S. Lotto, A. Moya, D. Allemand, and J. Adkins. 2007. Characterization and role of carbonic anhydrase in the calcification process of the azooxanthellate coral Tubastrea aurea. Marine Biology 151:71-83.

Thatje S., K. Anger, J.A. Calcagno, G.A. Lovrich, H.-O. Portner, and W.E. Arntz. 2005. Challenging the cold: Crabs reconquer the Antarctic. Ecology 86(3):619-625.

Wood, H.L., J.I. Spicer, and S. Widdicombe. 2008. Ocean acidification may increase calcification rates, but at a cost. Proceedings of the Royal Society B 275:1,767-1,773.

Yamamoto-Kawai, M., F.A. McLaughlin, E.C. Carmack, S. Nishino, and K. Shimada. 2009. Aragonite undersaturation in the Arctic Ocean: Effects of ocean acidification and sea ice melt. Science 326(5956):1,098-1,100, doi:10.1126/ science.1174190. 